\title{
Salicylic Acid and Calcium Treatments Improves Wheat Vigor, Lipids and Phenolics Under High Salinity
}

\author{
Nilgün Candan Yücel ${ }^{1, *}$ and Elif Hakl1 Heybet ${ }^{2}$ \\ ${ }^{1}$ Chemistry Department, Dokuz Eylul University, Faculty of Science, Buca, 35160, Izmir, Turkey \\ ${ }^{2}$ Biology Department, Cukurova University, Faculty of Science and Art, 01150, Sarıçam, Balcalı, Adana, Turkey \\ * Corresponding author: E-mail: nilgun.candan@deu.edu.tr \\ Tel: +902323019540
}

Received: 21-03-2016

\begin{abstract}
Seed vigor is a complex physiological trait required to ensure the rapid and uniform emergence of plants in the field under different environmental conditions. Therefore, salicylic acid $(\mathrm{SA}, 0.5 \mathrm{mM})$ and calcium $\left(\mathrm{Ca}^{2+}, 50 \mathrm{mM}\right)$ priming were used as exogenous growth enhancers to stimulate wheat (Triticum durum Desf. cv. Yelken) seed vigor under high salinity. The main aim was to address whether priming of wheat with $\mathrm{SA}, \mathrm{Ca}^{2+}$ and $\mathrm{SA}+\mathrm{Ca}\left(\mathrm{SA}, 0.5 \mathrm{mM}+\mathrm{Ca}^{2+}, 50 \mathrm{mM}\right.$; their combination) could bring about supplementary agronomic benefits particularly under stressful environments such as salinity. Exogenous application of SA or $\mathrm{Ca}^{2+}$ alone improved plant behavior in the presence of salinity stress. Nevertheless, the best results in terms of growth, seed vigor and total phenolic - flavonoids, chlorophyll - carotenoids contents and phenylalanine ammonia-lyase (PAL), ascorbic acide oxidase (AAO) activities and lipid peroxidation levels (LPO) were obtained in response to the combined SA+Ca treatment.
\end{abstract}

Keywords: Calcium, phenolic contents, Salicylic acid, salinity stress, wheat

\section{Introduction}

The world's population is expected to triple between 1950 ( 2.5 billion) and 2020 (7.5 billion). A major objective of plant sciences is to increase our food production; current estimates indicated that we need to increase production by $70 \%$ in the next years. ${ }^{1}$ Crop productivity is detrimentally affected by abiotic and biotic factors and the most important one is salt stress. ${ }^{2,3}$ Thus, it is important that develop new strategies to alleviate the negative effects of salt on seed germination thereby crop establishment on saline soils.

In a recent review, Chen and Arora highlighted the use of seed priming to improve stress tolerance in germination process, according to their hypothesis that treatments inducing the activation of pre-germinative metabolism might imprint in seeds a sort of "stress memory' or 'priming memory'. Thus, improvement tolerance capacity of seed germination can provide by direct application of nutrients or plant growth regulators to seeds via priming. ${ }^{4}$

Tolerant plants have developed strategies to cope with salt stress, including anatomical, morphological and metabolic mechanisms that adjust their physiology and metabolism to accommodate osmotic stress. With relation to improving seed vigour through stimulation of phenolic synthesis, it has been suggested that exogenously applied phenolic antioxidants may be able to stimulate endogenous phenolic content in plants. ${ }^{5}$ High phenolic content leads to better seed vigour.

Salicylic acid (SA) is a plant phenolic and also hormone-like endogenous regulator, its role in the defence mechanisms has been well characterized. ${ }^{6-8}$ Applied salicylic acid (SA) resumes the activation of a range of plant defense response genes and a large variety of plant physiological processes; seed germination, stomatal closure, glycolysis and fruit yield. ${ }^{9}$ SA activates defense response genes by acting as a signal in a transduction pathway. ${ }^{10}$ Szepsi et al. reported that increased accumulation of proline in plants exposed to salinity stress which was amplified by salicylic acid treatment. ${ }^{11}$ As an elicitor, SA regulates the phenylalanine ammonia-lyase (PAL) enzyme activity, which catalyzes biosynthetic reactions for forming defensive compounds like phenolics. ${ }^{12}$

Calcium $\left(\mathrm{Ca}^{2+}\right)$ is another signal molecule and major mineral nutrient and its content is affected by phyto- 
hormones in plants. Salt stress can trigger a transient increase in cytosolic $\mathrm{Ca}^{2+}$, and intracellular $\mathrm{Ca}^{2+}$ plays a key role in the regulation of proline metabolism. Du and coworkers ${ }^{13}$ suggested that there exists a regulatory mechanism linking $\mathrm{Ca}^{2+}$ signaling to $\mathrm{SA}$ level. SA or $\mathrm{Ca}$ alone as well as in combination significantly improved proline concentration. ${ }^{14}$

The present study investigated whether exogenous $\mathrm{SA}$ and $\mathrm{Ca}^{2+}$ could improve the seed germination of wheat via increasing phenolic contents under salinity stress. A range of plant physiological reactions to SA application are known, but more extensive studies focusing on the effects of SA on phenolic contents under high salinity are still lacking. Also, the aim of the present study was to examine whether SA, $\mathrm{Ca}^{2+}$ used singly or in combination-induced increases in the resistance of wheat to salinity stress.

In this study the effect of exogenous $\mathrm{SA}$ and $\mathrm{Ca}^{2+}$ priming on wheat vigour response were investigated PAL, peroxidase (POD), ascorbic acid oxidase (AAO) activities, total phenolics-flavonoids, proline and lipid peroxidation contents. Also the changes in seed vigor measurement include germination percentage, shoot weight, shoot and root height under salinity stress (0\%-non saline, 10\%moderate, $30 \%$-high saline).

\section{Experimental}

\section{1. Plant Material and Seed Treatment}

Ten $g$ of wheat cultivar (Triticum durum Desf. cv. Yelken) seeds were soaked in each treatment (salicylic acid (SA), calcium $\left(\mathrm{Ca}^{2+}\right)$ and combination of both treatments) with shaking at $150 \mathrm{rpm}$ overnight.

\section{2. Salinity Experiments}

To examine the effects of salinity on germination percentages replicates of 15 seeds were sown on non-cellulosic paper in $500 \mathrm{~mL}$ plastic containers. The seeds were constantly based-watered. Containers were sealed to prevent evaporation and maintained at $20{ }^{\circ} \mathrm{C}$ in a growth cabinet illuminated $\left(25 \mu \mathrm{mol} \mathrm{m} \mathrm{m}^{-2} \mathrm{~s}^{-1} 400-700 \mathrm{~nm}\right)$ on a 14-h day/10-h night regime. Seeds were considered germinated with the emergence of the radicle. Three salinity concentrations $(0 \%, 10 \%, 30 \%)$ were tested $(450 \mathrm{mM}$ sodium choloride).

Firstly, salicylic acid was dissolved in $100 \mu \mathrm{L}$ dimethyl sulfoxide and then $0.5 \mathrm{mM} \mathrm{SA}(\mathrm{pH} 6.5)$ was prepared with distilled water containing $0.02 \%$ Tween 20 .

\section{3. Germination Percentages, Shoots Length, and Roots Length}

Seeds were considered to be germinated when the radicle emerged through the seed coat and reached more than $2 \mathrm{~mm}$ in length. The number of germinated seeds for each cultivar and treatment was recorded every day. Germination percentages (GP) were calculated using the following equations:

$\mathrm{GP}=\mathrm{n} / \mathrm{N} \times 100 \%$, where $\mathrm{n}$ is the number of germination, and $\mathrm{N}$ represents the total number of tested seeds.

The weight of whole seedlings (roots included) was measured.

\section{4. Enzyme Determinations}

For enzyme determination: one gram of germinating seeds and seedlings were ground and homogenized in 4 $\mathrm{ml}, 20 \mathrm{mM}$ phosphate buffer ( $\mathrm{pH}$ 7.4). The homogenate was filtered and then centrifuged at $15.000 \times g$ for $15 \mathrm{~min}$.

The enzymatic assay of phenylalanine ammonialyase (EC 4.3.1.5) activity was measured Hodgins method. ${ }^{17}$ Assay concentrations contained $150 \mathrm{mM}$ Tris HC1 pH 8.5 buffer, 3 mM L-phenylalnine and ezyme.

The guaiacol-dependent peroxidase (EC 1.11.1.7) activity assay was composed of $25 \mathrm{mM}$ phosphate buffer (pH 7.0), 0.05\% guaiacol, $10 \mathrm{mM} \mathrm{H}_{2} \mathrm{O}_{2}$, and enzyme. Activity was determined by the increase in absorbance at 470 $\mathrm{nm}$ due to guaiacol oxidation $\left(E=26.6 \mathrm{mM}^{-1} \mathrm{~cm}^{-1}\right){ }^{18}$

Estimation of ascorbic acid oxidase (AAO) activity was determined by the method of Oberbacher and Vine the rate of oxygen consumption during ascorbic acid oxidation is proportional to the amount of enzyme present. ${ }^{19}$ Ascorbate oxidase activity was assayed at $25{ }^{\circ} \mathrm{C}$ by following the decrease in A265 of the reaction mixture containing $0.05 \mathrm{M}$ potassium phosphate buffer $(\mathrm{pH}$ 7.0), $0.5 \mathrm{~mm}$ EDTA, $0.002 \%$ metaphosphoric acid, 0.15 $\mathrm{mM}$ L-ascorbic acid, and enzyme solution in a final volume of $3.0 \mathrm{~mL}$, according to the method of Oberbacher and Vines ${ }^{19}$. One unit of enzyme activity was defined as the amount of enzyme that oxidizes $1.0 \mu \mathrm{mol}$ of L-ascorbic acid per min.

\section{5. Analytical Methods}

Proline content was determined as follows. ${ }^{20}$ Fifth $\mathrm{mg}$ (root, shoot and seed) was weighed and added 3\%, 1.2 $\mathrm{ml}$ of sulphosalicylic acid to precipitate protein. The samples were centrifuged at $18.000 \times \mathrm{g}$ for $15 \mathrm{~min}$ and then supernatant was diluted 1:1 with distilled water. Thereafter, $1 \mathrm{ml}$ glacial acetic acid and $1 \mathrm{ml}$ ninhydrin reagent [prepared 3\% (w/v) ninhydrin in $60 \%(\mathrm{v} / \mathrm{v}) 6 \mathrm{M}$ phosphoric acid] added. Tubes kept for $1 \mathrm{~h}$ at $90{ }^{\circ} \mathrm{C}$ after cooling in ice. The products were extracted with $2 \mathrm{ml}$ of toluene then mixed by vortex. Solvent decanted into a glass cuvette and absorbance read at $520 \mathrm{~nm}$.

Total phenolic content in wheat samples were taken on first, third, fifth day of germination and was determined according to McCue method. ${ }^{15}$ Approximately $50 \mathrm{mg}$ of each sample was placed in $2.5 \mathrm{~mL}$ of $95 \%$ ethanol and frozen for 48-72 h. Samples were homogenized and centrifuged at $10.000 \mathrm{~g}$ for $10 \mathrm{~min}$. One milliliter supernatant 
was combined with $1 \mathrm{~mL} 95 \%$ ethanol $+5 \mathrm{~mL}$ distilled water $+0.5 \mathrm{~mL}$ of $50 \%$ Folin-Ciocalteu phenol reagent. After a $5 \mathrm{~min}$ incubation period, $1 \mathrm{~mL}$ of $5 \%(\mathrm{w} / \mathrm{v})$ sodium carbonate was added and brief vortexed. The reaction mixture was incubated for $1 \mathrm{~h}$ in a dark-cupboard and the absorbance at $725 \mathrm{~nm}$ was determined and gallic acid $(25-200 \mu \mathrm{g} / \mathrm{mL})$ was used as a phenolic standard curve.

The flavonoid content in the crude extract was determined $\mathrm{Du}$ and co-workers method with some modifications. ${ }^{16}$ Briefly, $10 \mathrm{mg}$ sample extracted with the solvent of $30 \%$ ethanol. Then the solution treated with $1 \mathrm{~mL}$ of $5 \%(\mathrm{w} / \mathrm{v})$ sodium nitrite for $6 \mathrm{~min}$, followed by reaction with $1 \mathrm{~mL}$ of $10 \%(\mathrm{w} / \mathrm{v})$ aluminum nitrate to form complex for $6 \mathrm{~min}$. Then $10 \mathrm{~mL}$ of $4 \%(\mathrm{w} / \mathrm{v}) \mathrm{NaOH}$ was added and the total volume was supplemented to $25 \mathrm{~mL}$ with $30 \%$ ethanol. A series of standards of rutin in the range of $10-80 \mu \mathrm{g} / \mathrm{mL}$ were prepared in $30 \%$ ethanol solution and the absorbance was measured at $510 \mathrm{~nm}$ by UV-vis spectrophotometer.

LPO was estimated based on thiobarbituric acid (TBA) reactivity. Samples were evaluated for malondialdehyde (MDA) production using a spectrophotometric assay for TBA. ${ }^{21}$ The extinction coefficient of $153 \mathrm{mM}^{-1}$ $\mathrm{cm}^{-1}$ at $532 \mathrm{~nm}$ for the chromophore was used to calculate the MDA-like TBA produced.
Concentrations of $\mathrm{Chl}(\mathrm{a}+\mathrm{b})$ and carotenoids were measured as described by Lichtenthaler and Wellburn after extraction with $80 \%$ acetone. $^{22}$

The protein content was determined by Bradford method using bovine serum albumin (BSA) as a standard. $^{23}$

\section{Results and Discussion}

\section{1. Germination Percentages, Shoots Length, and Roots Length}

The seeds of wheat germinated in four different treatments, control, salicylic acid (SA) $(0.5 \mathrm{mM})$, calcium $\left(\mathrm{Ca}^{2+}\right)(50 \mathrm{mM})$ and combination of SA and $\mathrm{Ca}^{2+}(0.5 \mathrm{mM}$ and $50 \mathrm{mM}$ ) at the three salinity levels (control, $0 \%$ nonsaline; 10\%-moderate; 30\%-high $\mathrm{NaCl}$-saline) were analyzed during plant growth on the 1st, 3rd and 5th days. Percentage of seed germination, shoot, root length and also fresh weight were studied (Table 1).

The level of germination percentages and fresh weights (FW) in wheat seedlings grown under various salinity stresses increased from day 1 to 5 in absence as well as in the presence of SA, $\mathrm{Ca}^{2+}$ and $\mathrm{SA}+\mathrm{Ca}$. The germination percentage was gradually and significantly reduced

Table 1. Growth parameters:\% germination, Fresh weight of wheat four different treatments; control, $0.5 \mathrm{mM} \mathrm{SA}, 50 \mathrm{mM}$ $\mathrm{Ca}^{2+}$, and acombination of SA+Ca under non-saline and 10\%-30\% salinity stress.

\begin{tabular}{|c|c|c|c|c|c|}
\hline \multirow{2}{*}{$\begin{array}{l}\text { Growth } \\
\text { parameters }\end{array}$} & \multirow{2}{*}{ Salinity } & \multirow{2}{*}{ Traetment } & \multicolumn{3}{|c|}{ Plant growth (in days) } \\
\hline & & & 1 & 3 & 5 \\
\hline \multirow{12}{*}{$\begin{array}{l}\% \\
\text { Germination }\end{array}$} & \multirow{4}{*}{0} & Control & $96 \pm 01$ & $97 \pm 01$ & $98 \pm 02$ \\
\hline & & SA & $96 \pm 03$ & $98 \pm 01$ & $98 \pm 01$ \\
\hline & & $\mathrm{Ca}^{2+}$ & $96 \pm 03$ & $97 \pm 02$ & $98 \pm 01$ \\
\hline & & $\mathrm{SA}+\mathrm{Ca}$ & $97 \pm 02$ & $99 \pm 01$ & $100 \pm 01$ \\
\hline & \multirow{4}{*}{$10 \%$} & Control & $52 \pm 04$ & $62 \pm 03$ & $75 \pm 02$ \\
\hline & & SA & $80 \pm 04$ & $93 \pm 02$ & $95 \pm 03$ \\
\hline & & $\mathrm{Ca}^{2+}$ & $80 \pm 03$ & $92 \pm 02$ & $94 \pm 03$ \\
\hline & & $\mathrm{SA}+\mathrm{Ca}$ & $95 \pm 02$ & $97 \pm 01$ & $99 \pm 02$ \\
\hline & \multirow{4}{*}{$30 \%$} & Control & $20 \pm 05$ & $32 \pm 06$ & $40 \pm 02$ \\
\hline & & SA & $71 \pm 05$ & $88 \pm 06$ & $92 \pm 05$ \\
\hline & & $\mathrm{Ca}^{2+}$ & $70 \pm 06$ & $80 \pm 03$ & $85 \pm 01$ \\
\hline & & $\mathrm{SA}+\mathrm{Ca}$ & $92 \pm 06$ & $95 \pm 04$ & $96 \pm 03$ \\
\hline \multirow{12}{*}{$\begin{array}{l}\text { Fresh weight } \\
\text { (mg) }\end{array}$} & \multirow{5}{*}{0} & Control & $74 \pm 3$ & $95 \pm 3$ & $100 \pm 5$ \\
\hline & & SA & $95 \pm 4$ & $115 \pm 6^{\varepsilon}$ & $125 \pm 6^{\varepsilon}$ \\
\hline & & $\mathrm{Ca}^{2+}$ & $94 \pm 3$ & $101 \pm 5^{\delta}$ & $107 \pm 4^{\delta}$ \\
\hline & & $\mathrm{SA}+\mathrm{Ca}$ & $104 \pm 2^{\varepsilon}$ & $116 \pm 4^{\varepsilon}$ & $118 \pm 3^{\varepsilon}$ \\
\hline & & Control & $64 \pm 5$ & $83 \pm 3$ & $89 \pm 3$ \\
\hline & \multirow{3}{*}{$10 \%$} & SA & $87 \pm 2^{\delta}$ & $97 \pm 2$ & $105 \pm 4^{\delta}$ \\
\hline & & $\mathrm{Ca}^{2+}$ & $83 \pm 3^{\delta}$ & $89 \pm 3^{\delta}$ & $90 \pm 3$ \\
\hline & & $\mathrm{SA}+\mathrm{Ca}$ & $93 \pm 4^{\varepsilon}$ & $100 \pm 4^{\varepsilon}$ & $120 \pm 5^{\varepsilon}$ \\
\hline & \multirow{4}{*}{$30 \%$} & Control & $54 \pm 3$ & $69 \pm 4$ & $73 \pm 3$ \\
\hline & & SA & $69 \pm 5^{\delta}$ & $85 \pm 5^{\delta}$ & $98 \pm 2^{\varepsilon}$ \\
\hline & & $\mathrm{Ca}^{2+}$ & $65 \pm 2^{\delta}$ & $76 \pm 3^{\delta}$ & $78 \pm 3$ \\
\hline & & $\mathrm{SA}+\mathrm{Ca}$ & $85 \pm 3^{\varepsilon}$ & $91 \pm 3^{\varepsilon}$ & $112 \pm 6^{\varepsilon}$ \\
\hline
\end{tabular}

Data are 'mean \pm S.D' anda re averages of 10 seedlings. ${ }^{\delta} \mathrm{p}<0.05$ (probably significant) ${ }^{\varepsilon} \mathrm{p}<0.01$ (definitely significant) 
by salinity, particularly in the high salinity conditions over the treatment period when compared to non-saline control (Table 1). However, the rates were gradually recovered by $\mathrm{SA}, \mathrm{Ca}^{2+}$, and $\mathrm{SA}+\mathrm{Ca}$ treatments under non-saline control and moderate and high salinity stress when compared to their controls. The priming treatments in the order of increasing germination percentage of the wheat seedlings were $\mathrm{Ca}<\mathrm{SA}<\mathrm{SA}+\mathrm{Ca}$ under salinity $(p<0.01)$. Germination percentage levels in wheat seeds primed with $\mathrm{SA}+\mathrm{Ca}$ resulted in a 1.8 -fold increase on the $1^{\text {st }}$ day under moderate salinity when compared to control. The maximum increases of germination percentage were obtained from $20 \pm 05$ to $92 \pm 06 \%$ in wheat seeds primed with $\mathrm{SA}+\mathrm{Ca}$ on the $1^{\text {st }}$ day under high salinity. The germination percentage in wheat seeds primed with $\mathrm{SA}, \mathrm{Ca}^{2+}$ and $\mathrm{SA}+\mathrm{Ca}$ was not significant under non-saline conditions ( $\mathrm{p}$ $>0.05)$ (Table 1).

Table 1 showed that fresh weights (FW) were gradually decreased by salinity, while the values were recovered by $\mathrm{Ca}^{2+}, \mathrm{SA}$ and $\mathrm{SA}+\mathrm{Ca}$ treatments, respectively. Fresh weight levels in wheat seeds primed with $\mathrm{SA}+\mathrm{Ca}$ resulted in a 1.4-fold increase under moderate salinity and a 1.6-fold increase under high salinity on the $1^{\text {st }}$ day as compared to non-saline control. However, the effect of priming (with $\mathrm{SA}, \mathrm{Ca}^{2+}$ and $\mathrm{SA}+\mathrm{Ca}$ ) on $\mathrm{FW}$ was not sig- nificant under non-saline control. The FW values in the control seedlings primed with distilled water (no SA or Ca) reduced from $74 \pm 3$ to $54 \pm 3 \mathrm{mg}$ with an increase of salinity from 0 to $30 \%$ on the $1^{\text {st }}$ day and the difference between these values increased during the period of exposure.

The shoot length showed a negative correlation with $(r=-0.419)$ the severity of salinity stress in the course of the treatment period and reached their minimum (by a 1.84 -fold decrease) under high salinity on the $5^{\text {th }}$ day (Table 2). The shoot length levels in the control seedlings primed with distilled water reduced from $1.0 \pm 0.1$ to 0.5 $\pm 0.2 \mathrm{~cm}$ with increase salinity from 0 to $30 \%$ at the $1^{\text {st }}$ day and the difference between these values increased during the period of exposure. The levels in wheat plants grown from seeds primed with $\mathrm{SA}, \mathrm{Ca}^{2+}$ and $\mathrm{SA}+\mathrm{Ca}$ five days after sowing was significantly renewed under moderate and high salinity.

The level of root length in wheat seedlings grown under various salinity stresses increased from day 1 to 5 in absence as well as in the presence of $\mathrm{SA}, \mathrm{Ca}^{2+}$ and $\mathrm{SA}+\mathrm{Ca}$. The root length showed a negative correlation with $(r=-0.620, p<0.01)$ the severity of salinity stress in the course of the treatment period and reached their minimum (by a 2.66-fold decrease) under high salinity on the

Table 2. Growth parameters: shoot and root lenght of wheat four different treatments; control, $0.5 \mathrm{mM} \mathrm{SA}, 50 \mathrm{mM} \mathrm{Ca}^{2+}$, and acombination of SA+Ca under non-saline and 10\%-30\% salinity stress.

\begin{tabular}{|c|c|c|c|c|c|}
\hline \multirow{2}{*}{$\begin{array}{l}\text { Growth } \\
\text { parameters }\end{array}$} & \multirow{2}{*}{ Salinity } & \multirow{2}{*}{ Traetment } & \multicolumn{3}{|c|}{ Plant growth (in days) } \\
\hline & & & $\mathbf{1}$ & 3 & 5 \\
\hline \multirow{12}{*}{$\begin{array}{l}\text { FW } \\
(\mathrm{g})\end{array}$} & \multirow{4}{*}{0} & Control & $1.0 \pm 0.1$ & $2.0 \pm 0.2$ & $2.4 \pm 0.1$ \\
\hline & & SA & $1.5 \pm 0.3^{\delta}$ & $2.3 \pm 0.1^{\delta}$ & $2.5 \pm 0.1$ \\
\hline & & SA & $1.6 \pm 0.3^{\delta}$ & $2.3 \pm 0.2^{\delta}$ & $2.5 \pm 0.1$ \\
\hline & & SA & $1.8 \pm 0.2^{\delta}$ & $2.8 \pm 0.1^{\delta}$ & $3.1 \pm 0.1^{\delta}$ \\
\hline & \multirow{4}{*}{$\mathrm{NaCl}$} & Control & $0.7 \pm 0.2$ & $1.1 \pm 0.3$ & $2.0 \pm 0.2$ \\
\hline & & SA & $1.4 \pm 0.4^{\delta}$ & $2.0 \pm 0.2^{\delta}$ & $2.2 \pm 0.3$ \\
\hline & & $\mathrm{Ca}^{2+}$ & $1.1 \pm 0.3^{\delta}$ & $1.7 \pm 0.2$ & $1.9 \pm 0.3$ \\
\hline & & $\mathrm{SA}+\mathrm{Ca}$ & $1.5 \pm 0.2^{\delta}$ & $2.5 \pm 0.1^{\delta}$ & $2.9 \pm 0.2^{\delta}$ \\
\hline & \multirow{4}{*}{$30 \%$} & Control & $0.5 \pm 0.1$ & $1.3 \pm 0.2$ & $1.3 \pm 0.2$ \\
\hline & & SA & $0.7 \pm 0.5$ & $1.7 \pm 0.6$ & $2.0 \pm 0.5^{\delta}$ \\
\hline & & $\mathrm{Ca}^{2+}$ & $0.6 \pm 0.1$ & $1.3 \pm 0.3$ & $1.7 \pm 0.5$ \\
\hline & & $\mathrm{SA}+\mathrm{Ca}$ & $1.3 \pm 0.5^{\delta}$ & $1.8 \pm 0.4^{\delta}$ & $2.5 \pm 0.3^{\delta}$ \\
\hline \multirow{12}{*}{$\begin{array}{l}\text { Root lenght } \\
(\mathrm{cm})\end{array}$} & \multirow{5}{*}{0} & Control & $2.0 \pm 0.3$ & $3.5 \pm 0.3$ & $4.0 \pm 0.2$ \\
\hline & & SA & $3.7 \pm 0.4^{\delta}$ & $4.5 \pm 0.6$ & $5.0 \pm 0.6$ \\
\hline & & $\mathrm{Ca}^{2+}$ & $3.5 \pm 0.3^{\delta}$ & $4.4 \pm 0.5$ & $4.6 \pm 0.4$ \\
\hline & & $\mathrm{SA}+\mathrm{Ca}$ & $4.4 \pm 0.2^{\varepsilon}$ & $5.0 \pm 0.4^{\delta}$ & $5.7 \pm 0.3^{\delta}$ \\
\hline & & Control & $1.0 \pm 0.5$ & $1.9 \pm 0.3$ & $2.5 \pm 0.3$ \\
\hline & \multirow{3}{*}{$10 \%$} & SA & $2.5 \pm 0.2^{\varepsilon}$ & $3.5 \pm 0.2$ & $3.8 \pm 0.4^{\delta}$ \\
\hline & & $\mathrm{Ca}^{2+}$ & $2.1 \pm 0.3^{\varepsilon}$ & $3.0 \pm 0.3$ & $3.3 \pm 0.3^{\delta}$ \\
\hline & & $\mathrm{SA}+\mathrm{Ca}$ & $4.0 \pm 0.4^{\varepsilon}$ & $4.7 \pm 0.4^{\delta}$ & $4.7 \pm 0.5$ \\
\hline & \multirow{4}{*}{$30 \%$} & Control & $0.5 \pm 0.2$ & $1.3 \pm 0.4$ & $1.5 \pm 0.3$ \\
\hline & & $\mathrm{SA}$ & $1.2 \pm 0.5^{\delta}$ & $3.0 \pm 0.5^{\delta}$ & $3.5 \pm 0.2^{\varepsilon}$ \\
\hline & & $\mathrm{Ca}^{2+}$ & $1.0 \pm 0.2^{\delta}$ & $2.1 \pm 0.3^{\delta}$ & $2.5 \pm 0.3^{\delta}$ \\
\hline & & $\mathrm{SA}+\mathrm{Ca}$ & $3.5 \pm 0.3^{\varepsilon}$ & $4.5 \pm 0.3^{\varepsilon}$ & $4.5 \pm 0.6^{\varepsilon}$ \\
\hline
\end{tabular}

Data are 'mean \pm S.D' anda re averages of 10 seedlings. ${ }^{\delta} \mathrm{p}<0.05$ (probably significant) ${ }^{\varepsilon} \mathrm{p}<0.01$ (definitely significant) 
$5^{\text {th }}$ day. The priming treatments in the order of increasing root length of the wheat seedlings were $\mathrm{Ca}^{2+}<\mathrm{SA}<$ $\mathrm{SA}+\mathrm{Ca}$ under salinity $(p<0.01)$.

Germination tests give the best factors for germination in order to exploit all the potential of seeds especially under stress conditions. Salinity stress, is one of the important stress factor in seed development of agriculture worldwide (or physiologically induced drought), causes both a reduction in germination percentage of seeds and in the initiation of the germination process and then, seedlings to high risks of mortality. ${ }^{24}$ The seed ability to withstand dehydration is an essential requisite for enhancing seed longevity and vigor, and ensuring successful germination under stress conditions.

In our study; germination percentages, fresh weight, shoot and root lengths were gradually decreased with increasing salinity stress. It is also well documented that the plants on being exposed to high salinity, result in a decline in their metabolic activity, thereby leading to retarded overall growth. ${ }^{25}$ However, salinity induced retardation of growth in wheat was to a great extent alleviated by the application of salicylic acid ${ }^{26}$. Salicylic acid (SA) and calcium are recognized as signal molecules, and have been intensively investigated for their roles in plant adaptation for changing environments. Especially, SA was found to improve plant tolerance mechanisms to salinity stress. ${ }^{27,28}$ Another strategy that partially alleviates the deleterious effects of saline stress on plants is the nutrient supply (as $\mathrm{Se}, \mathrm{N}, \mathrm{Ca})$ in order to reduce $\mathrm{Na}^{+}$and $\mathrm{Cl}^{-}$injures in plants. ${ }^{29,30}$

\section{2. Proline Content}

As can be seen in Figure 1, proline contents of the wheat seedlings increased with time under salinity stress. The contents in plants grown from seeds primed with distilled water (no SA or $\mathrm{Ca}^{2+}$ ) showed a positive correlation with $(r=0.840, p<0.01)$ the severity of salinity stress in the course of the treatment period and reached their maximum (by a 1.40-fold increase) under high salinity on the $5^{\text {th }}$ day (Figure 1). Also, the exogenous stimulator were ordered with respect to the rates of increase in the contents as $\mathrm{Ca}^{2+} \leq \mathrm{SA}<\mathrm{SA}+\mathrm{Ca}$. The maximum phenolic contents was found 4.1-, 2.4- and 2.4-fold increase in plants grown from seeds primed with $\mathrm{SA}+\mathrm{Ca}$ as compared to their control on the 3rd day under non-saline, moderate and high salinity, respectively (Figure 1a,b,c).

The SA application also regulated the proline accumulation and decreased the toxic ion $(\mathrm{Cl})$ accumulation, both in shoot and storage root. In our study, salinity stress and the applications of $\mathrm{SA}, \mathrm{Ca}^{2+}$ and $\mathrm{SA}+\mathrm{Ca}$ enhanced significantly proline content. Another study reported by Szepsi et al (2005) has also shown increased accumulation of proline in plants exposed to salinity stress which was amplified by SA treatment. ${ }^{11}$ The accumulation of proline following SA treatment has also been shown in
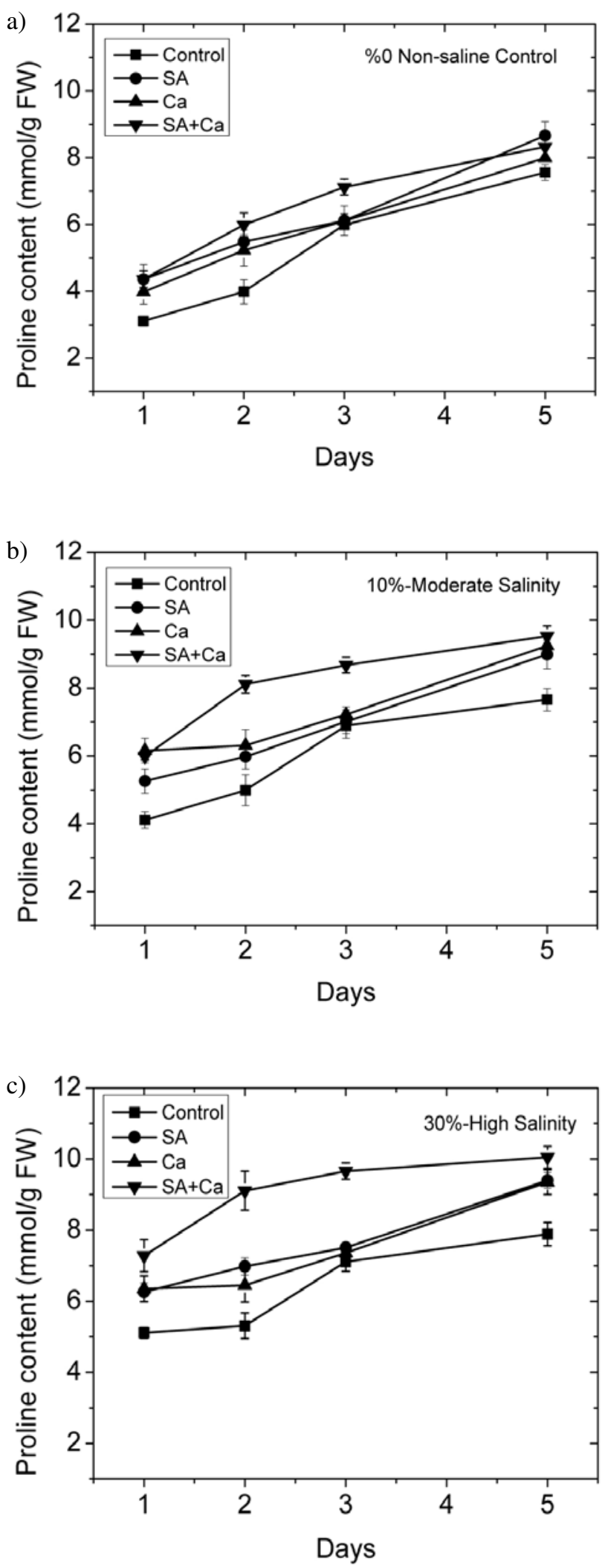

Figure 1. Proline contents in seedlings of wheat under three different stres conditions a) Non-saline b) 10\%-Moderate salinity and c) 30\%-High salinity: with four traetments (-ם-), control;

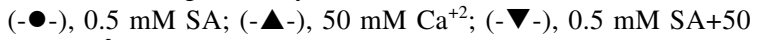
$\mathrm{mM} \mathrm{Ca}{ }^{+2}$. 
Triticum aestivum, Avena aestivum and Phaseolus vulgaris plants. ${ }^{31} \mathrm{SA}$ treatments have shown increased protective action of ABA, proline content and defensive proteins in Triticum under salinity. ${ }^{32}$ Chen and co-workers have shown that proline induces Ca-medaited SA signaling. ${ }^{33}$

\section{3. Enzyme Activities, Total Phenolic, Flavonoid Contents and Other Analytical Parameters}

Gua-dep peroxidase activity in seedlings of wheat grown under various treatments from day 1 to 5 in non-saline control as well in all treated samples (Figure 2). Guadep peroxidase activity in plants grown from seeds primed with distilled water (no SA or $\mathrm{Ca}^{2+}$ ) showed a positive correlation with $(r=0.670, p<0.01)$ the severity of salinity stress in the course of the treatment period and reached their maximum (by a 2.20-fold increase) under high salinity on the $5^{\text {th }}$ day (Figure 2). The priming treatments in the order of increasing Gua-dep POD activity of the wheat seedlings were $\mathrm{Ca}^{2+}<\mathrm{SA}<\mathrm{SA}+\mathrm{Ca}$ under non-saline control. The maximum activity of Gua-dep peroxidase was found 1.5-fold increase in plants grown from seeds primed with $0.5 \mathrm{mM} \mathrm{SA}+20 \mathrm{mM} \mathrm{Ca}^{2+}$ as compared to control on the 2nd day under non-saline control (Figure 2a).

The Gua-dep POD activities display different responses depending on $\mathrm{Ca}^{2+}$ treatment under salinity stress (Figure 2b,c). While the activities in wheat plants grown from seeds primed with $\mathrm{Ca}^{2+}$ were higher than the control under non-saline conditions, the levels were lower than the control under salinity stress. The lowest activity was found for $\mathrm{Ca}^{2+}$ treatment under high salinity. Gua-dep POD activity in wheat plants grown from seeds primed with SA resulted in 2-fold increase for the initial period for germination, while the activities were significantly below the control level in the rest of the germination period under salinity stress.

The maximum activity of Gua-dep peroxidase was found 1.6-fold increase in plants grown from seeds primed with $0.5 \mathrm{mM} \mathrm{SA}+50 \mathrm{mM} \mathrm{Ca}^{2+}$ as compared to their control on the 5th day under high salinity.

The present work showed that under both non-saline and salinity stress conditions, the exogenous application of $\mathrm{Ca}^{2+}$ alone, had an ameliorative effect on seed vigor (germination\%, FW) of tested wheat seeds group, but had not any positive effect on Gua-dep POD activities under salinity stress. Gua-dep POD is an enzyme involved in secondary metabolism which can polymerize phenolics monomers together and is involved in the lignifications process that adds strength to plant cell wall during growth. In general, increased Gua-dep POD activities seems to mirror increased plant growth (height and weight). The slight increase in phenolics content observed in $\mathrm{Ca}^{2+}$ treatment may be indicative of increased phenolics synthesis to support increased growth via Gua-dep POD activity/lignin biosynthesis and also increasing PAL activities.
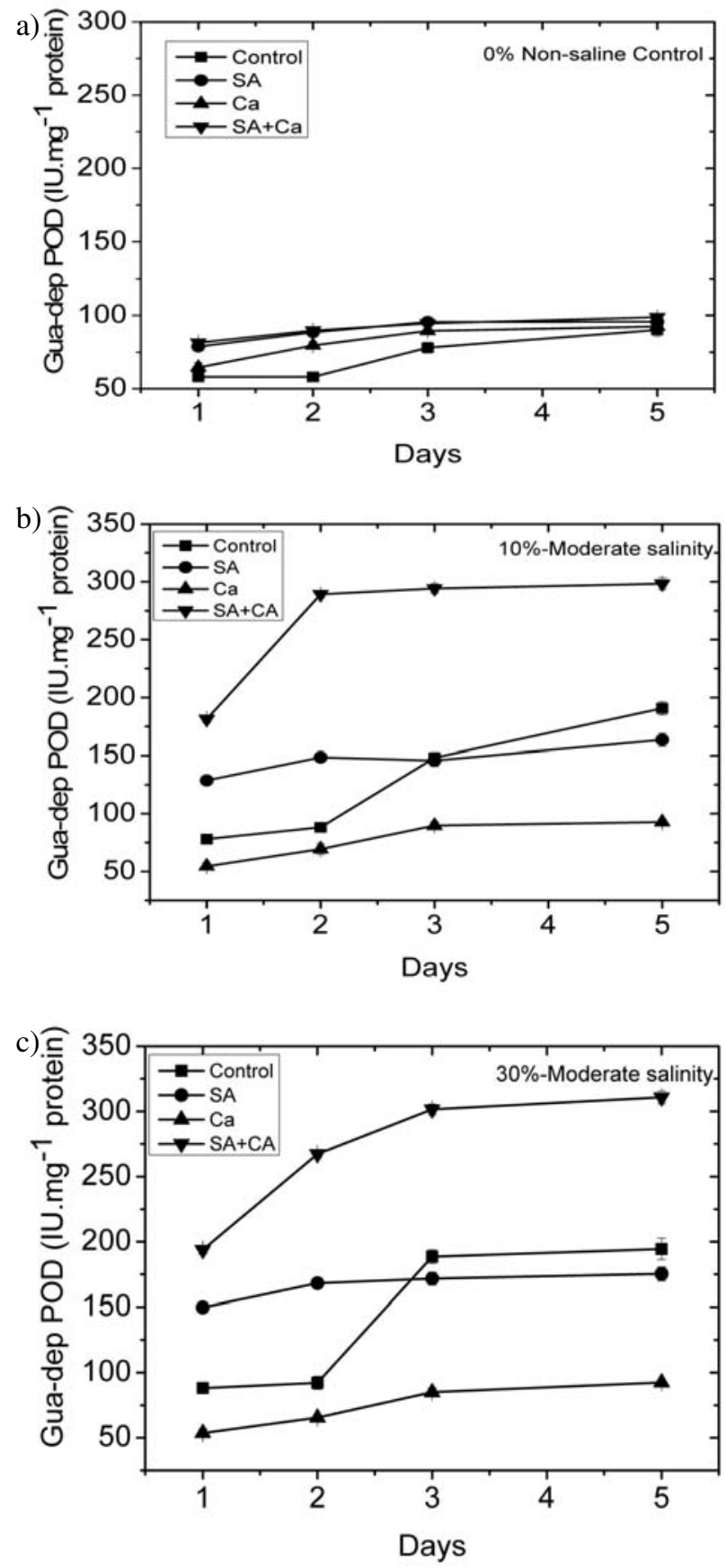

Figure 2. Activity of Gua-dep POD activities in seedlings of wheat under three different stres conditions a) Non-saline b) 10\%-Moderate salinity and c) 30\%-High salinity: with four traetments (-口-),

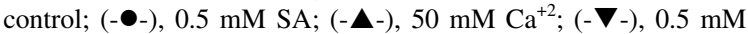
$\mathrm{SA}+50 \mathrm{mM} \mathrm{Ca}^{+2 .}$

Table 3 shows chlorophyll, carotenoid contents, PAL and AAO enzyme activities and also LPO levels for $\mathrm{Ca}^{2+}$, SA effects under control and high saline control conditions. In relation to wheat cultivar, combination $(\mathrm{SA}+\mathrm{Ca})$ treatment had higher non-photosynthetic pigment $\left(\beta\right.$-carotene) contents than $\mathrm{SA}>\mathrm{Ca}^{2+}>$ control, respectively. Salinity stress resulted in massive increase 
Table 3. Parameters: Chlorophyll, carotenoid and LPO content, PAL and AAO activities; control, $0.5 \mathrm{mM} \mathrm{SA}, 50 \mathrm{mM} \mathrm{Ca}^{2+}$, and combinations of $\mathrm{SA}+\mathrm{Ca}$ under non-saline and $30 \%$ salinity stress.

\begin{tabular}{|c|c|c|c|c|c|}
\hline \multirow{2}{*}{ Parameter } & \multirow[b]{2}{*}{ No salinity } & \multicolumn{2}{|l|}{ Control } & \multicolumn{2}{|l|}{ 30\% Salinity } \\
\hline & & $30 \%$ Salinity & 0.5 mM SA & $50 \mathrm{mM} \mathrm{Ca} \mathrm{Ca}^{2+}$ & $\mathbf{S A}+\mathbf{C a}$ \\
\hline$\overline{\text { Chlorophylls }\left(\mu \mathrm{g} . \mathrm{cm}^{-2}\right)}$ & $158 \pm 06$ & $168 \pm 07$ & $270 \pm 08$ & $171 \pm 05$ & $183 \pm 03$ \\
\hline Carotenoids $\left(\mu \mathrm{g} . \mathrm{cm}^{-2}\right)$ & $2.1 \pm 0.3$ & $2.9 \pm 0.1$ & $5.7 \pm 0.3$ & $3.1 \pm 0.2$ & $6.5 \pm 0.5$ \\
\hline PAL (IU.mg ${ }^{-1}$ protein) & $32 \pm 0.4$ & $45 \pm 02$ & $98 \pm 04$ & $52 \pm 01$ & $118 \pm 02$ \\
\hline AAO (IU.mg ${ }^{-1}$ protein) & $0.5 \pm 0.1$ & $0.7 \pm 0.1$ & $1.38 \pm 0.3$ & $0.9 \pm 0.2$ & $2.5 \pm 0.4$ \\
\hline LPO (nmol MDA.g $\left.{ }^{-1}\right)$ & $5 \pm 1.2$ & $7 \pm 1.1$ & $4 \pm 1.1$ & $6 \pm 1.2$ & $2.1 \pm 1.1$ \\
\hline
\end{tabular}

$(\mathrm{p} \geq 0.05)$ in the non-photosynthetic pigment content. Application $\mathrm{SA}$ and/or $\mathrm{Ca}^{2+}$ induced additional increase $(\mathrm{p} \geq 0.05)$ in $\beta$-carotene contents. The effect was more pronounced with SA treatment in case of cholorophyll pigment and with SA and $\mathrm{Ca}^{2+}$ treatment in case of $\beta$-carotene pigment.

Application SA and/or Ca markedly increased $(\mathrm{p} \geq 0.05) \mathrm{AAO}$ and PAL activities in seedlings of wheat grown under high $\mathrm{NaCl}$ treatment. Generally, SA and $\mathrm{Ca}$ treatment appeared to be the most effective treatment in counteracting the negative effects of salt stress on AAO, POD and PAL activities.

As can be seen in Figure 3, the total soluble phenolic contents of the wheat seedlings increased with time under salinity stress. The contents in plants grown from seeds primed with distilled water (no SA or $\mathrm{Ca}^{2+}$ ) showed a positive correlation with $(r=0.790, p<0.01)$ the severity of salinity stress in the course of the treatment period and reached their maximum (by a 3.45-fold increase) under high salinity on the $5^{\text {th }}$ day (Figure 3 ). Also, the exogenous stimulator were ordered with respect to the rates of increase in the phenolic contents as $\mathrm{Ca}^{2+}<\mathrm{SA}<\mathrm{SA}+\mathrm{Ca}$. The maximum phenolics contents was found as $8.32,9.53$ and $10.05 \mathrm{mmol} / \mathrm{g} \mathrm{FW}$ in plants grown from seeds primed with $\mathrm{SA}+\mathrm{Ca}$ on the 5 th day under non-saline, moderate and high salinity, respectively (Figure 3a,b,c).

In the present study, the salt-exposed plants treated with both $\mathrm{SA}$ and $\mathrm{Ca}^{2+}$ exhibited enhanced alleviating the adverse effects of salt stress on seed vigour, total proline and phenolic contents than SA application alone. It may thus be hypothesized that $\mathrm{SA}$ and $\mathrm{Ca}^{2+}$ act as signaling compounds in an additive or even synergistic way that induces ameliorative effects on the growth potential and phenolic content of stressed plants. Indeed, simultaneous application of $\mathrm{Ca}^{2+}$ and $\mathrm{SA}$ gave better results than exogenous application of $\mathrm{Ca}^{2+}$ or $\mathrm{SA}$ alone for some of the parameters conditioning plant growth. Our data proving this information is lipid peroxidation levels of bio-membranes. Salt stress is resulted the harmful free radical production and membranes are primary sites of injury to cells. In our study, increasing LPO levels of salt stressed wheat plants also were more decreased by application of SA and $\mathrm{Ca}^{2+}$ combination treatment.

The degree of cellular membrane damage reflects the measure of plant tolerance to stresses.
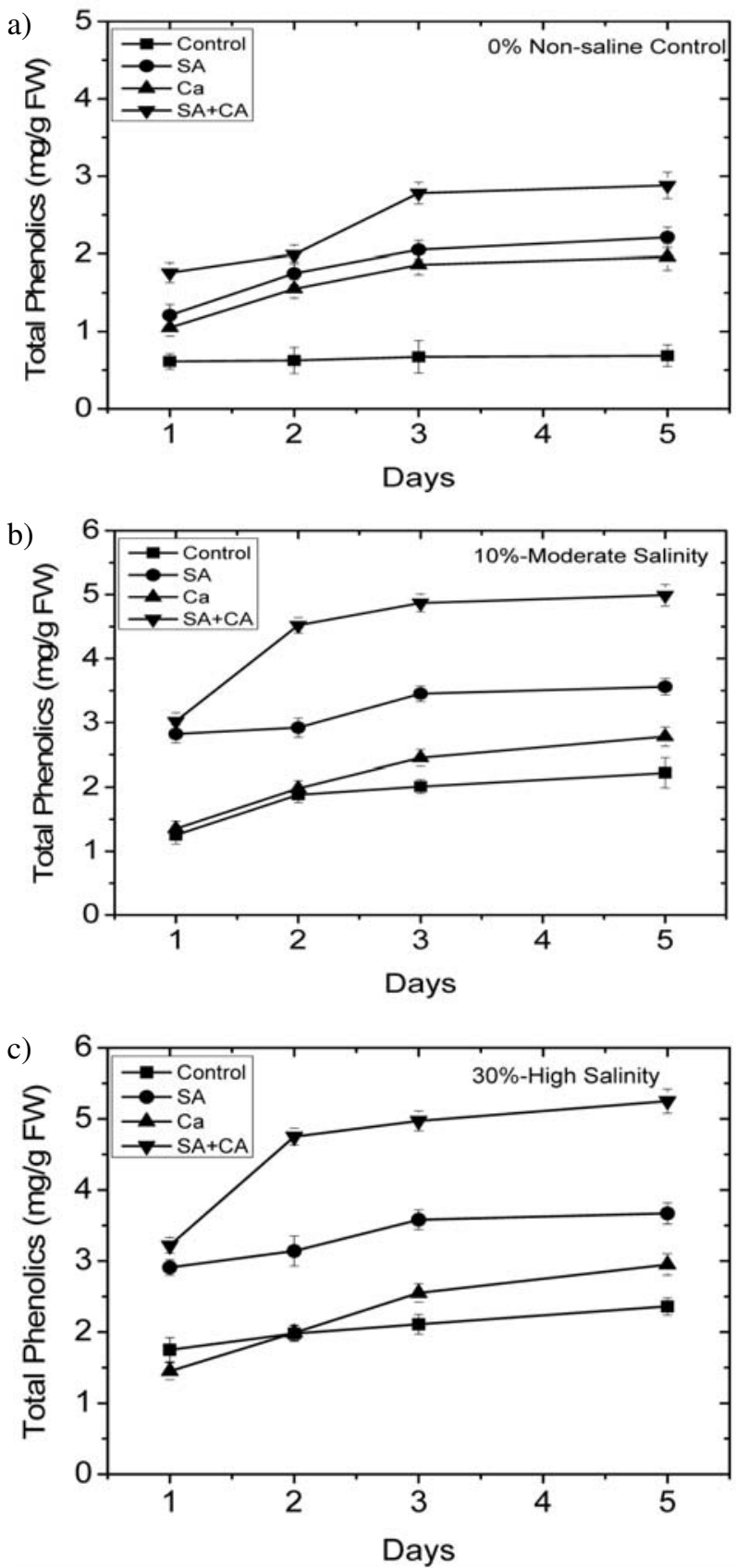

Figure 3. Total Phenolic contents in seedlings of wheat under three different stres conditions a) Non-saline b) $10 \%$-Moderate salinity and c) 30\%-High salinity: with four traetments (-口-), control; (-๑-),

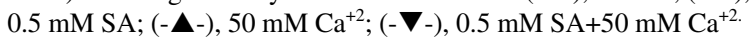


Like our study, exogenous SA application decreased LPO in sweet basil under salinity stress. ${ }^{34}$ Sufficient calcium concentration is required at all stages of plant growth and development, playing a fundamental role in regulation polar growth of cells and tissues and participating in plant adaptation to various stress factors. ${ }^{34}$

Salicylic acid synthesized in cells can move freely in and out of the cells, ${ }^{35}$ tissues and organs and this movement is finely regulated by $\mathrm{Ca}^{2+}$ and ROS. ${ }^{36}$

Generally, SA and Ca treatment appeared to be the most effective treatment in counteracting the negative effects of salt stress on AAO and POD activities. Collectively, the enhanced antioxidant activities of wheat plants under the studied circumstances were in close parallelism with the enhanced accumulation of various antioxidant metabolites. Application of SA and/or Ca markedly increased total phenols and flavonoid contents. Generally, $\mathrm{SA}$ and $\mathrm{Ca}$ treatment appeared to be the most effective treatment in counteracting the negative effects of salt stress on total phenols and flavonoids contents.

It is believed that phenolic compounds play an important role in plant development. In the present study, the combinations of $\mathrm{Ca}^{2+}$ and SA treatment increased the average plant height and fresh weight. This treatment had a better response than $\mathrm{Ca}^{2+}$ and SA alone. The treatment with combinations of $\mathrm{Ca}^{2+}$ and SA had the best effect on wheat vigor response compared to other treatments in this study. SA may be involved in the phenylpropanoid pathway when combined with $\mathrm{Ca}^{2+}$ and SA may have had a cumulative effect. These results showed that the combinations of $\mathrm{Ca}^{2+}$ and $\mathrm{SA}$ treatment enhanced the production of phenolics, therefore leading to better seed vigor which was translated into plant height and fresh weight. It is believed that phenolics compounds play an important role in plant development.

\section{Conclusions}

The purpose of this study was to investigate whether exogenous SA and $\mathrm{Ca}^{2+}$ could improve the seed germination of wheat via increasing phenolic contents under salinity stress.

We observed a substantial increase in proline levels with both treatments, which might be attributed to the strategies adapted by plants to cope up with stress conditions. Proline can thus be considered as an important component protective reaction of wheat plants in response to salinity, contributing to a reduction in the injurious effects of salinity. These experimental data suggest that environmental stresses selectively induce those entire primary (proline) as well as secondary metabolic activities that are directly and indirectly involved in the accumulation of phenolics compounds. A possible sequence of biochemical reactions inside the cell, which transfer an environmental signal from the outside of the cell into the plant cell, thus producing a physiological response, could be envisaged.

From the results of this study we concluded that the role of SA signify in regulating the salt stress response to wheat, and suggested that combination of $\mathrm{SA}$ and $\mathrm{Ca}^{2+}$ could be used as a potential growth regulator to improve plant growth under salinity stress.

\section{References}

1. Food and Agricultural Organization (FAO) 2009, Land and plant Nutrition Management Service. www.fao.org/wsfs/forum2050/

2. M. Almansouri, J. M. Kinet, S. Lutts, Plant Soil, 2001, 231, 243-254. http://dx.doi.org/10.1023/A:1010378409663

3. N. Misra, U. N. Dwivedi, Plant Sci., 2004, 166, 1135-1142. http://dx.doi.org/10.1016/j.plantsci.2003.11.028

4. K. Chen, R. Arora, Environ. Exp. Bot., 2013, 94, 33-45. http://dx.doi.org/10.1016/j.envexpbot.2012.03.005

5. R. Rhandir, K. Shetty, Process Biochem., 2003, 38, 945-952. http://dx.doi.org/10.1016/S0032-9592(02)00219-4

6. N. Yalpani, A.J. Enyedi, J. Leon, I. Raskin, Planta, 1994, 35, 117-125.

7. M. Waseem, H. U. R. Athar, M. Ashraf, Pak. J. Bot., 2006, $38,1127-1136$.

8. M. Arfan, H. R. Athar, M. Ashraf, J. Plant Physiol., 2007, 6, 685-694. http://dx.doi.org/10.1016/j.jplph.2006.05.010

9. J. Ryals, S. Uknes, E. Ward, Plant Physiol., 1994, 104, 1109-1112. http://dx.doi.org/10.1104/pp.104.4.1109

10. R. A. Dixon, N. L. Paiva, M. K. Bhattacharyya, Molecular Methods in Plant Pathology, Boca Raton, FL. CRC Press, 1995, 249-70.

11. A. Szepsi, J. Csiszar, K. Gemes, E. Horvath, F. Horvath, M. L. Simon, L. Tari. J. Plant Physiol., 2005, 166, 914-925. http://dx.doi.org/10.1016/j.jplph.2008.11.012

12. J. Zhao, L. T. Davis, R. Verpoort, Biotechnol. Adv., 2005, 23 , 283-333. http://dx.doi.org/10.1016/j.biotechadv.2005.01.003

13. L. Duo, G. S. Ali, K. A. Simons, J. Hou, T. Yang, A. S. Reddy, B. W. Poovanah, Nature, 2009, 457, 1154-1158. http://dx.doi.org/10.1038/nature07612

14. M. H. Al-Whaibi, M. H. Siddiqui, M. O. Basalah, Protoplasma, 2012, 249, 769-778. http://dx.doi.org/10.1007/s00709-011-0322-1

15. P. McCue, Z. Zheng, J. L. Pinkham, K. Shetty, Process. Biochemi., 2000, 35, 60-613. http://dx.doi.org/10.1016/S0032-9592(99)00111-9

16. R. J. Du, C. L. Zhang, N. Ling, J. F. Li, X. H. Hou, J. Shenyang Pharm. Univ., 2013, 30, 298-301.

17. D. S. Hodgins, J. Biol. Chem., 1971, 246, 2977-2985.

18. Y. Nakano, K. Asada, Plant Cell Physiol., 1981, 22, 867- 880.

19. M. F. Oberbacher, H. M. Vines, Nature, 1963, 197, 12031204. http://dx.doi.org/10.1038/1971203a0

20. L. S. Bates, R. P. Waldren, I. D. Teare, Plant Soil, 1973, 39, 205-207. http://dx.doi.org/10.1007/BF00018060 
21. J. A. Buege, S. D. Aust, Methods Enzymol., 1978, 52, 464 478. http://dx.doi.org/10.1016/S0076-6879(78)52032-6

22. H. K. Lichtenthaler, A. R. Wellburn, Biochem. Soc. Trans., 1983, 11, 591-592. http://dx.doi.org/10.1042/bst0110591

23. M. M. Bradford, Anal. Biochem., 1976, 72, 248-254. http://dx.doi.org/10.1016/0003-2697(76)90527-3

24. J. A. Pujol, J. F. Calvo, L. R. Diaz, Annu. Bot., 2000, 85, 279-286. http://dx.doi.org/10.1006/anbo.1999.1028

25. S. Ramagopal, Plant Physiol., 1987, 84, 324-331. http://dx.doi.org/10.1104/pp.84.2.324

26. F. M. Shakirova, In: Hayat, S., Ahmad, A. (Eds.). Salicylic acid. Springer, Netherlands. 2007.

27. S. Gautam, P. Singh, Acta Physiol. Plant, 2009, 31, 11851190. http://dx.doi.org/10.1007/s11738-009-0338-8

28. S. Wasti, H. Mimouni, S. Smiti, E. Zid, B. A. Hela, J. Integr. Biol.i 2012, 16, 200-207.

29. L. Kong, M. Wang, S. Bi, Plant Growth Regul., 2005, 45, 155-163. http://dx.doi.org/10.1007/s10725-005-1893-7
30. C. Kaya, H. Kırnak, D. Higgs, K. Saltali, Hort. Sci., 2002, 93, 65-74. http://dx.doi.org/10.1016/S0304-4238(01)00313-2

31. E. Tasgin, O. Atici, B. Nulbantoglu, L. P. Popova, Phytochem., 2006, 67, 710-715. http://dx.doi.org/10.1016/j.phytochem.2006.01.022

32. F. M. Shakirova, D. R. Sakhabutdinova, Plant Sci., 2003, 164, 317-322. http://dx.doi.org/10.1016/S0168-9452(02)00415-6

33. J. Chen, Y. Zhang, C. Wang, W. Lu, J. D. Jin, X. Hua, Amino Acids, 2011, 40, 1473-1484 http://dx.doi.org/10.1007/s00726-010-0757-2

34. J. Y. Song, J. H. Roe, T. J. Microbiol., 2008, 46, 408-414. http://dx.doi.org/10.1007/s12275-008-0076-4

35. T. Kawano, T. Furuichi, S. Muto, Plant Biotechnol., 2004, 21, 319-335. http://dx.doi.org/10.5511/plantbiotechnology.21.319

36. H. J. Chen, J. Kuc, Bot. Bul. Acad. Sinica, 1999, 40, 267273.

\section{Povzetek}

Klitje semen je kompleksna fiziološka lastnost, ki mora zagotoviti hiter in enoten pojav rastlin na poljih v različnih okoljskih pogojih. Zato smo uporabili salicilno kislino $(\mathrm{SA}, 0,5 \mathrm{mM})$ in kalcij $\left(\mathrm{Ca}^{2+}, 50 \mathrm{mM}\right)$ kot sprožilca in zunanja pospeševalca rasti pšenice (Triticum durum Desf. Cv. Yelken) iz semen v pogojih visoke slanosti. Glavni cilj je bil odgovoriti na vprašanje, če sprožanje klitja pšenice z SA, $\mathrm{Ca}^{2+}$ in $\mathrm{SA}+\mathrm{Ca}\left(\mathrm{SA}, 0.5 \mathrm{mM}+\mathrm{Ca}^{2+}, 50 \mathrm{mM}\right.$; v kombinaciji) lahko prinese dodatne agronomske koristi, predvsem v stresnih okoljih, kot je visoka slanost. Zunanja uporaba $\mathrm{SA}_{\text {ali }} \mathrm{Ca}^{2+}$ je izboljšala obnašanje rastlin v prisotnosti stresa slanosti. Najboljše rezultate v smislu rasti, klitja semen in vsebnosti fenolnih - flavonoidov, klorofilaI - karotenoidnih vsebin, fenilalanin amoniak-liaze (PAL), monoaminooksidaze askorbinske kisline (AAO) in ravni peroksidacije lipidov (LPO), pa smo dobili kot odgovor na kombinirano tretiranje s SA + $\mathrm{Ca}$. 